\title{
PENGARUH KEDALAMAN TANAM SPROUT TERHADAP PERTUMBUHAN VEGETATIF TANAMAN KENTANG (Solanum tuberosum L.) DI BPTP SUMATERA BARAT
}

\author{
Disi Asrani, Nahda Kanara \\ Program Studi Budi Daya Tanaman Hortikultura Jurusan Budi Daya Tanaman Pangan \\ Politeknik Pertanian Negeri Payakumbuh, Jl.Raya Negara KM.7 Tanjung Pati 26271 \\ Kecamatan Harau Kabupaten Lima Puluh Kota Sumatera Barat \\ Email:
}

\begin{abstract}
ABSTRAK
Tanaman kentang (Solanum tuberosum L.) merupakan tanaman semusim yang berbentuk semak. Permintaan kentang dari tahun ke tahun terus meningkat, dikarenakan kentang memiliki protein dan vitamin yang cukup tinggi. Salah satu kegiatan yang dapat menunjang budidaya tanaman kentang adalah kegiatan pembibitan. Kegiatan ini sangat penting dilakukan dengan tujuan untuk mendapatkan tanaman sesuai dengan yang diharapkan sehingga dapat meningkatkan produktivitas dari tanaman tersebut. Pembibitan tanaman kentang dapat dilakukan menggunakan sprout kentang dengan berbagai kedalaman tanam. Pada kedalaman tanam harus disesuaikan dengan kondisi tanah. Untuk dataran tinggi dengan kelembaban udara yang relatif tinggi, penanaman dangkal yang semakin mendekat permukaan tanah, lebih dianjurkan.Tujuan dari penelitian ini adalah mengetahui pengaruh kedalaman tanam terhadap pertumbuhan vegetatif sprout kentang, dan mendapatkan kedalaman tanam terbaik dari perbanyakan sprout kentang.

Penelitian ini telah dilaksanakan pada bulan Februari - Maret 2019. di Balai Pengkajian Teknologi Pertanian Sumatera Barat. Perlakuan yang diberikan adalah kedalaman tanam $2 \mathrm{~cm}$ (KT2), kedalaman tanam $3 \mathrm{~cm}$ (KT3), kedalaman tanam $4 \mathrm{~cm}$ (KT4), dan kedalaman tanam $5 \mathrm{~cm}$ (KT5). Parameter yang diamati pada percobaan ini adalah, tinggi tanaman, lebar daun, panjang daun dan jumlah tangkai daun. Hasil yang didapat dari percobaan ini adalah perlakuan yang terbaik terdapat KT4, untuk tinggi tanaman dan lebar daun, sedangkan untuk parameter panjang daun yang paling baik pada perlakuan KT2, dan untuk parameter jumlah tangkai daun yang paling baik pada perlakuan KT5. Oleh karena itu, kedalaman tanam $4 \mathrm{~cm}$ adalah perlakuan yang paling baik untuk penanaman sprout kentang.
\end{abstract}

Kata Kunci: kedalaman tanam, kentang, sprout, stek tunas umbi.

PENDAHULUAN

Kentang (Solanum tuberosum L) merupakan tanaman umbi yang kaya akan karbohidrat dan merupakan salah satu makanan pokok dunia karena berada pada peringkat ketiga tanaman yang dikonsumsi masyarakat dunia setelah beras dan gandum. Kentang dianggap sebagai salah satu sayuran yang mendapat prioritas karena dapat mendatangkan keuntungan bagi petani, mempunyai prospek yang baik dalam pemasaran dan ekspor. Kentang juga merupakan salah satu makanan pokok terpenting pada beberapa negara. Bagian utama tanaman kentang yang menjadi bahan makanan adalah umbi. Umbi kentang merupakan sumber karbohidrat yang mengandung vitamin mineral cukup tinggi. Komposisi utama umbi kentang terdiri dari air $80 \%$, pati $18 \%$, dan protein $2 \%$. Kentang merupakan sumber kalori yang tinggi, mengandung protein, lemak, karbohidrat dan vitamin B1, B2, dan C (Balai Pengkajian Teknologi Pertanian, 2015).

Di Indonesia produksi kentang semakin menurun, menurut Badan Pusat Statistik dan Direktorat Jenderal Hortikultura, produksi kentang di Indonesia menurun dari 1.219.270 ton pad atahun 2015 menjadi 1.213.038 ton pada tahun 2016, demikian mengalami penurunan produksi 
$0,51 \%$, produktivitasnya pada 18.20 ton/ha tahun 2015 menjadi 18.25 ton/ha tahun 2016 (BPS, 2017). Produksi kentang di kabupaten Solok 19,81 ton/ha tahun 2017 (BPS, 2018) terjadi penurun produksi dari tahun 2016, jumlah produksi 19,88 ton/ha.

Rendahnya produktivitas kentang di Indonesia disebabkan oleh beberapa hal, salah satunya di tahap perbanyakan. Permasalahan di tahap tersebut antara lain rendahnya mutu bibit yang digunakan petani, tingginya biaya produksi bibit, pengetahuan kultur teknis masih kurang. Penanaman kentang secara terus menerus, umur panen yang kurang tepat, penyimpanan yang kurang baik, permodalan yang terbatas, dan yang paling utama adalah faktor kehilangan hasil akibat serangan hama dan penyakit (Setiawati, 2007).

Upaya perbanyakan tanaman kentang dapat dilakukan dengan cepat melalui perbanyakan secara vegetatif, Kelebihan perbanyakan tanaman dengan cara vegetatif antara lain masa muda tanaman relatif pendek, tanaman lebih cepat bereproduksi, dapat diterapkan pada tanaman yang tidak menghasilkan biji, sifat-sifat yang lebih baik pada induknya dapat diturunkan, dapat tumbuh pada tanah yang memiliki lapisan tanah dangkal karena memiliki sistem perakaran yang dangkal, salah satunya adalah sprout (stek tunas umbi). Sprout adalah bahan perbanyakan tanaman yang berupa tunas yang berasal dari umbi. Stek ini tersusun oleh bagian tanaman yang minimal memiliki satu helai daun dan dua primordial akar. Metode perbayakan bibit dengan sprout telah dikembangkan oleh Hamman pada tahun 1974 (Balai Pengkajian Teknologi Pertanian Jambi, 2010 dan Ashari, 2008)

Salah satu faktor yang mempengaruhi keberhasilan pada pertumbuhan stek tunas umbi pada kedalaman tanam, kedalaman tanam tergantung dari suhu dan kondisi kelembaban di sekitar daerah perakaran. Dalam kegiatan penanaman disesuaikan dengan kondisi tanah. Untuk dataran tinggi dengan kelembaban udara yang relatif tinggi, penanaman dangkal yang semakin mendekat permukaan tanah, lebih dianjurkan (Balai Penelitian Tanaman Sayuran, 2007).

Semakin dalam kedalaman tanam maka benih yang ditanam akan semakin sulit tumbuh. Sebaliknya apabila benih ditanam pada kedalaman tanam yang dangkal, benih akan mudah tumbuh. Hal ini disebabkan oleh kadar oksigen yang terdapat di dalam tanah. Kadar oksigen akan semakin menurun dengan semakin dalam lapisan tanah (Ashari, 2006).

\section{Tujuan}

Tujuan dari penelitian ini adalah untuk mengetahui pengaruh kedalaman tanam terhadap pertumbuhan vegetatif sprout kentang dan mendapatka kedalaman tanam optimal dari perbanyakan sprout kentang.

\section{METODE PELAKSANAAN}

\section{Waktu dan Tempat}

Waktu pelaksanaan bulan Februari sampai Mei 2019 dan dilaksanakan di kebun percobaan BPTP (Balai Pengkajian Teknologi Pertanian) Sukarami Solok, Kabupaten Solok, Sumatera Barat.

\section{Alat dan Bahan}

Alat yang digunakan untuk melakukan budidaya tanaman sprout kentang di dalam polybag yaitu, gembor, seedbag, penggaris, pena, cangkul, sekop, gerobak, gelas ukur, dan pengaduk. Sedangkan bahan yang dibutuhkan adalah sprout kentang yang siap ditanam, 16 polybag, top soil, pupuk kandang ayam, 
arang sekam, formalin $2 \%$, air, TSP, KCL, pupuk Phonska, insektisida

\section{Perlakuan}

Kegiatan penelitian ini menggunakan 4 perlakuan dengan total 64 sampel.

Adapun perlakuan adalah sebagai berikut:

1. Kedalaman Tanam $2 \mathrm{~cm}$ (KT2)

2. Kedalaman Tanam $3 \mathrm{~cm}$ (KT3)

3. Kedalaman Tanam $4 \mathrm{~cm}$ (KT4)

4. Kedalaman Tanam $5 \mathrm{~cm}$ (KT5)

\section{Penyiapan Media tanam}

Media yang digunakan adalah top soil, pupuk kandang ayam, dan sekam bakar dengan perbandingan 3:2:1. Media tanah top soil, pupuk kandang ayam, dan sekam bakar dicampurkan hingga homogen dan dimasukkan ke dalam plastik uv sebagai wadah untukinkubasikan. Selanjutnya campuran media disiram dengan larutan formalin 2\%, yang dilarutkan dengan 10 liter air hingga merata pemberian formalin bertujuan untuk mensterilkan media dari mikoorganisme. Kemudian plastik diikat sampai tidak ada udara yang bisa masuk ke dalam plastik. Media yang disterilkan dan diinkubasikan selama $7-10$ hari.

\section{Pengadaan Bibit}

Bibit sprout yang digunakan sudah tersedia di persemaian BPTP Solok adalah bibit sprout kentang varietas granola. Jumlah bibit tanaman sprout kentang yang ditanam adalah 64 tanaman sprout kentang. kriteria bibit sprout yang harus yang digunakan adalah pertumbuhan yang sama, bebas dari hama dan penyakit, tidak cacat serta produktivitas yang tinggi.

\section{Penanaman}

Penanaman bibit sprout kentang dilakukan pada minggu terakhir tanggal 21
Februari. Penanaman dilakukan pada pagi hari dengan cara menanam lansung bibit sprout pada media tanam polybag. Sebelum penanaman dilakukan penyiraman media tanam dalam polibag hingga kapasitas lapang dan seluruh bagian media lembab. Selanjutnya, bibit sprout langsung ditanam pada polybag yang sudah berisi media dengan membuat lubang tanam tepat di tengah media dan padatkan sekitar pangkal batang tanaman supaya tanaman berdiri dengan kokoh.

\section{Pemberian perlakuan}

Perlakuan sprout kentang diberikan langsung pada daerah media tanam, dengan kedalaman tanam $2 \mathrm{~cm}$, kedalaman tanam 3 $\mathrm{cm}$, kedalaman tanam $4 \mathrm{~cm}$ dan kedalaman tanam $5 \mathrm{~cm}$. Langkah-langkah menentukan kedalaman tanam sprout kentang adalah sebagai berikut, seleksi sprout erlebih dahulu, setelah itu samakan tinggi sprout kemudian ukur bibit sprout dari bawah tanaman sampai di ukuran yang ditetapkan dengan menggunakan penggaris, kemudian ditandai dengan menggunakan pena, selanjutnya bibit sprout dipindahkan ke media tanam dengan jarak tanam 4-5 cm, selanjutnya ditanam dengan kedalaman tanam $2 \mathrm{~cm}$, kedalaman tanam $3 \mathrm{~cm}$, kedalaman tanam $4 \mathrm{~cm}$ dan kedalaman tanam $5 \mathrm{~cm}$.

\section{Penyiraman}

Penyiraman selanjutnya dilakukan setiap hari, penyiraman dilakukan dengan cara menyiramkan air ke bagian tanaman menggunakan gembor..

\section{Penyiangan Gulma}

Penyiangan dilakukan apabila gulma sudah dalam taraf mengganggu tanaman budidaya.

\section{Pemupukan}


Pemupukan susulan dilaksanakan sebanyak 1 kali, pemberian pupuk diberikan pada saat tanaman mencapai umur 4 hari setelah tanam, dengan dosis NPK Phonska: 20 gr, Sp36: 10 gr, KCl: 6 gr per tanaman.

\section{Pengendalian Hama dan Penyakit}

Pengendalian hama dilakukan dengan cara penyemprotan dengan hand sprayer, bertujuan untuk melakukan mencegah seranggan hama yang diberikan insektisida Winder dengan dosis $1 \mathrm{ml} / 1$ liter air.

\section{Parameter Pengamatan}

Pengamatan dilakukan dari minggu pertama setelah tanam sampai dengan minggu ke-9, pengamatan terdiri dari :

1. Tinggi tanaman, diukur dengan menggunakan penggaris mulai dari pangkal batang sampai ujung daun tertinggi, data didapatkan dalam satuan $\mathrm{cm}$.

2. Jumlah daun, dihitung daun sempurna, data didapatkan dalam satuan helai.

3. Panjang daun, diukur dengan menggunakan penggaris dari pangkal daun, data didapatkan dalam satuan $\mathrm{cm}$.

4. Lebar daun, diukur dengan mengguanakan penggaris dari bagian daun piling tengah,data didapatkan dalam satuan $\mathrm{cm}$.

\section{HASIL DAN PEMBAHASAN}

Tabel 1. Data Hasil Rata-rata pertumbuhan vegetatif pada minggu 9 Tinggi Tanaman, Lebar Daun, Panjang Daun, Jumlah Tangkai Daun

\begin{tabular}{|c|c|c|c|c|}
\hline $\begin{array}{l}\text { Perlaku } \\
\text { an }\end{array}$ & $\begin{array}{c}\text { Tingg } \\
\mathrm{i} \\
\text { tanam } \\
\text { an } \\
(\mathrm{cm})\end{array}$ & $\begin{array}{c}\text { Leb } \\
\text { ar } \\
\text { dau } \\
\mathrm{n} \\
(\mathrm{cm}\end{array}$ & $\begin{array}{c}\text { Panja } \\
\text { ng } \\
\text { daun } \\
(\mathrm{cm})\end{array}$ & $\begin{array}{c}\text { Jumlah } \\
\text { tangkai } \\
\text { daun } \\
\text { (Tangk }\end{array}$ \\
\hline
\end{tabular}

\begin{tabular}{|c|c|c|c|c|}
\hline & & ) & & ai) \\
\hline KT 2 & 30,8 & 5,8 & $\mathbf{9 , 3}$ & 8 \\
\hline KT 3 & 31,4 & 5,9 & 8,9 & 9 \\
\hline KT 4 & $\mathbf{3 2}$ & $\mathbf{6 , 1}$ & 6,5 & 9 \\
\hline KT 5 & 31,1 & 6 & 9 & $\mathbf{1 0}$ \\
\hline
\end{tabular}

Berdasarkan Tabel 1. Parameter ratarata tinggi tanaman tertinggi terdapat pada pelakuan KT4 dengan rata-rata $32 \mathrm{~cm}$ dan terendah pada perlakuan KT2 dengan ratarata $30,8 \mathrm{~cm}$. Rata-rata lebar daun tertinggi terdapat pada pelakuan KT4 dengan ratarata $6,1 \mathrm{~cm}$ dan terendah pada perlakuan KT2 dengan rata-rata $5,8 \mathrm{~cm}$

Parameter panjang daun, rata-rata panjang daun tertinggi terdapat pada pelakuan KT2 dengan rata-rata 9,3 cm dan terendah pada perlakuan KT4 dengan ratarata $6,5 \mathrm{~cm}$. Selanjutnya parameter jumlah tangkai daun, rata-rata jumlah tangkai daun tertinggi terdapat pada pelakuan KT5 dengan rata-rata 10 tangkai dan terendah pada perlakuan KT2 dengan rata-rata 8 tangkai.

\section{Tinggi Tanaman}

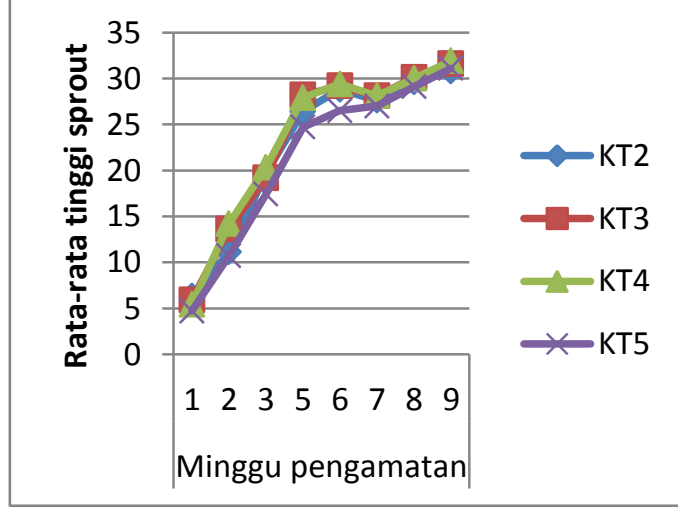

Gambar 1. Grafik Pertumbuhan Tinggi Tanaman Kentang

Dari grafik diatas dapat diketahui terjadi peningkatan tinggi tanaman pada seluruh perlakuan. Rata-rata tinggi tanaman tertinggi terdapat pada perlakuan KT4.

Kedalaman tanam pada sprout kentang sangat mempengaruhi pertumbuhan tanaman kentang. Semakin dalam kedalaman tanam maka benih yang ditanam 
akan semakin sulit tumbuh, tetapi berbeda dengan menggunakan sprout (tunas) kedalaman yang memberikan hasil tinggi yang terbaik.

Kedalaman tanam mempengaruhi pertumbuhan tinggi tanaman, karena pada pertumbuhan tinggi tanaman perlakuan kedalaman tanam yang baik akan memberikan hasil tertinggi. Karena hasil umbi ditentukan pada fase pertumbuhan vegetatif, semakin baik pertumbuhan tanaman ada kecenderungan akan menghasilkan jumlah umbi lebih banyak, karena jumlah umbi ditentukan pada fase pertumbuhan vegetatif (Khalafalla, 2001).

Dari hasil penelitian ini didapatkan rata-rata tinggi tanaman tertinggi pada perlakuan kedalaman tanan $4 \mathrm{~cm}$. Berdasarkan penelitian Fathulach (2017), Pada perlakuan kedalaman tanam perlakuan J1 $(10 \mathrm{~cm})$ memberikan hasil tertinggi pada pengamatan tinggi tanaman yaitu $56,28 \mathrm{~cm}$, tetapi tidak berbeda nyata dengan perlakuan lainnya.

\section{Lebar Daun, Panjang Daun dan Jumlah Daun}

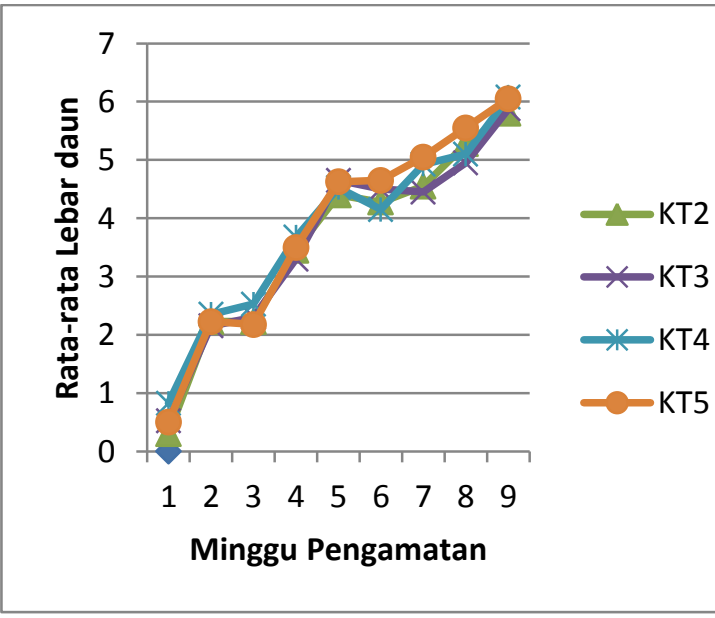

Gambar 2. Grafik Pertumbuhan Lebar Daun Tanaman Kentang
Dari grafik diatas dapat dilihat bahwa pada pertumbuhan lebar daun tanaman sprout kentang mengalami peningkatan yang baik pada perlakuan kedalaman tanam $5 \mathrm{~cm}$ dan kedalaman tanam $4 \mathrm{~cm}$.

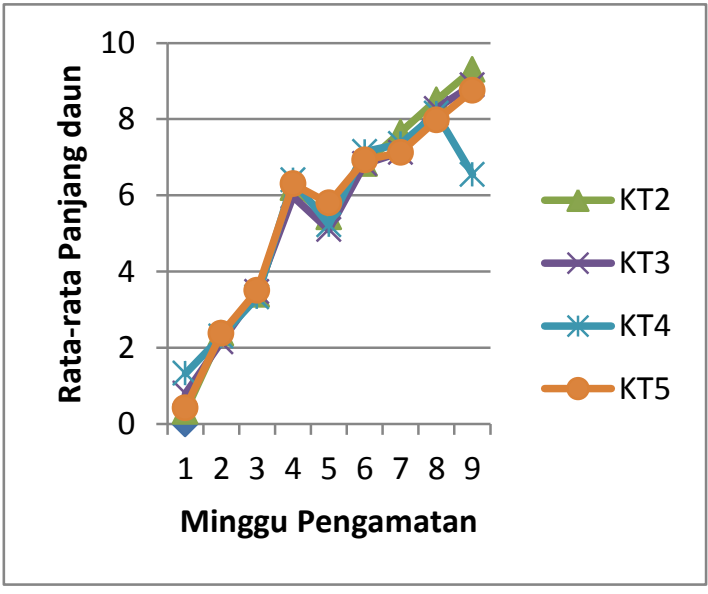

Gambar 3. Grafik Pertumbuhan Panjang

Daun Tanaman Kentang

Dari grafik diatas dapat dilihat bahwa pada pertumbuhan panjang daun tanaman sprout kentang mengalami peningkatan yang baik pada perlakuan kedalaman tanam $2 \mathrm{~cm}$.

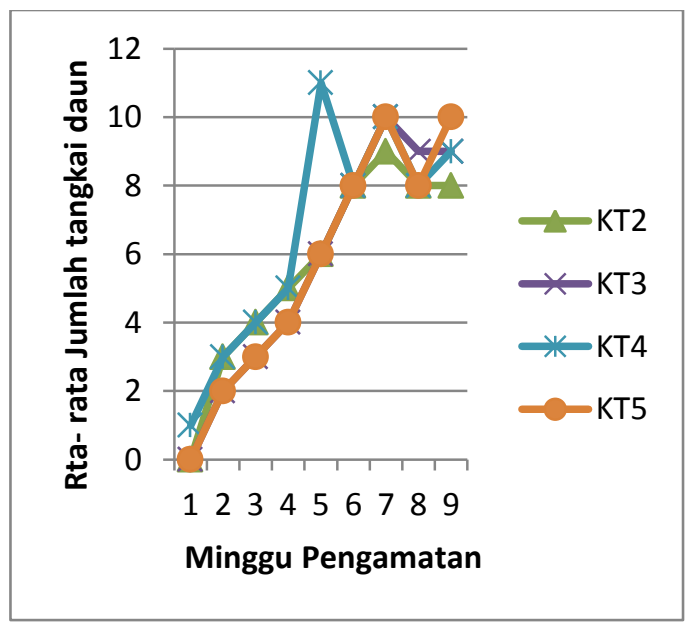

Gambar 4. Grafik Pertumbuhan Jumlah

Tangkai Daun Tanaman Kentang

Dari grafik diatas dapat dilihat bahwa pada pertumbuhan jumlah tangkai daun tanaman sprout kentang mengalami 
peningkatan yang baik pada perlakuan kedalaman tanam $4 \mathrm{~cm}$.

Pengamatan lebar daun tanaman sprout kentang yang paling baik terdapat pada perlakuan kedalaman tanam $4 \mathrm{~cm}$ sebesar $6,1 \mathrm{~cm}$. Pengamatan panjang daun tanaman sprout kentang memberikan hasil terbaik pada perlakuan kedalaman tanam 2 $\mathrm{cm}$ sebesar $9,3 \mathrm{~cm}$. Tidak terdapatnya pengaruh nyata pada perlakuan kedalaman tanam pada tanaman sprout kentang dengan kedalaman tanam kedalaman tanam $2 \mathrm{~cm}$, kedalaman tanam $3 \mathrm{~cm}$, kedalaman tanam 4 $\mathrm{cm}$ dan kedalaman tanam $5 \mathrm{~cm}$, dikarenakan kedalaman tanam tidak merangsang pemanjangan daun tanaman melainkan untuk memperkecil persaingan antara tanaman dalam penyerapan unsur hara dalam tanah, memperlebar perakaran dan merangsang pembentukan stolon. Pertumbuhan tanaman dipengaruhi oleh faktor genotipe tanaman dan lingkungan.

Hal ini sesuai dengan pendapat Gardner (1991), yang menyatakan bahwa pertumbuhan dan perkembangan tanaman dipengaruhi dan dikendalikan oleh faktor genotipe tanaman dan lingkungan.

Pengamatan jumlah tangkai daun sprout kentang dengan, perlakuan kedalaman tanam $5 \mathrm{~cm}$ memberikan hasil yang paling baik bila dibandingkan dengan perlakuan lainnya. Perbedaan jumlah tangkai daun disetiap perlakuan kedalaman tanam akan menyebabkan berbedanya kemampuan melakukan fotosintesis oleh masing-masing tanaman pada setiap perlakuan. Tumbuhan mengalami fotosintesis dan hasilnya energi-energi tersebut akan digunakan untuk pertumbuhan tanaman,dan sisanya akan disimpan oleh tanaman untuk dijadikan sebagai cadangan makanan.

Semakin dalam kedalaman tanah maka bibit yang ditanam akan semakin sulit tumbuh. Sebaiknya apabila bibit ditanam pada kedalaman tanam yang dangkal, bibit akan mudah tumbuh. Hal ini disebabkan oleh kadar oksigen yang terdapat di dalam tanah. Kadar oksigen akan semakin menurun dengan semakin dalam lapisan tanah (Ashari, 2006).

Faktor lingkungan yang mempengaruhi tanaman sprout kentang di dalam tanah adalah kelembaban tanah, suhu tanah, keasaman tanah, aerasi tanah, hambatan mekanis tanah. Semakin panjang masa pertumbuhan suatu tanaman, maka makin dalam akar menembus tanah. Semakin dalam tanah, semakin sedikit oksigen yang tersedia. Hal ini berarrti kecambah yang ditanam terlalu dalam akan mengalami kekurangan oksigen. Bila kekurangan oksigen maka respirasi akan terhambat yang mengakibatkan tertekannya pertumbuhan benih terutama dalam hal potensi tumbuh, daya berkecambah dan kecepatan tumbuh (Kamil, 1989).

Perlakuan kedalaman tanam tidak terdaptnya pengaruh mandiri, hal ini di duga kedalaman tanam berhubungan dengan vigor tanaman, karena bibit normal yang ditanam memiliki kekuatan tumbuh yang baik. Menurut Asandhi et al. (1993), perkembangan benih saat awal pertunasan sangat dipengaruhi oleh interaksi antara faktor genetik dan faktor lingkungan. Pecah tunas sangat ditentukan oleh ketuaan umbi dengan ketersediaan air sebagai pengurai bahan makanan yang terdapat pada umbi.

Perlakuan kedalaman tanam pada tanaman sprout kentang memberikan hasil optimal pada perlakuan kedalaman tanam 4 $\mathrm{cm}$ karena dari hasil pengamatan kedalaman tanam $4 \mathrm{~cm}$ unggul pada dua parameter pengamatan vegetatif yaitu tinggi tanaman dan lebar daun. Menurut Darwin (2000) dalam menanam benih atau bibit kedalaman tanam harus tepat karena apabila terlalu dalam atau terlalu dangkal menyebabkan pertumbuhan tanaman kurang baik. Penanaman yang terlalu dalam menyebabkan benih atau bibit mudah 
busuk, sedangkan bibit yang ditanam terlalu dangkal menyebabkan sistem perakaran kurang kuat dalam menopang tanaman sehingga tanaman mudah rebah sehinggan mengganggu pertumbuhan vegetatif tanaman.

\section{Kesimpulan \\ KESIMPULAN DAN SARAN}

Berdasarkan hasil dan pembahasan yang telah didapatkan dari penggalaman Kerja Praktek Mahasiswa, dapat kesimpulan sebagai berikut:

1. Parameter rata-rata pertumbuhan tinggi tertinggi terdapat pada perlakuan kedalaman tanam $4 \mathrm{~cm}$ untuk tinggi sprout kentang dan lebar daun, sedangkan untuk panjang daun yang paling baik pada perlakuan kedalaman tanam $2 \mathrm{~cm}$, dan untuk parameter jumlah tangkai daun yang paling baik pada perlakuan kedalaman tanam $5 \mathrm{~cm}$.

2. Perlakuan yang terbaik untuk kedalaman tanam sprout kentang adalah perlakuan kedalaman tanam 4 $\mathrm{cm}$.

Saran

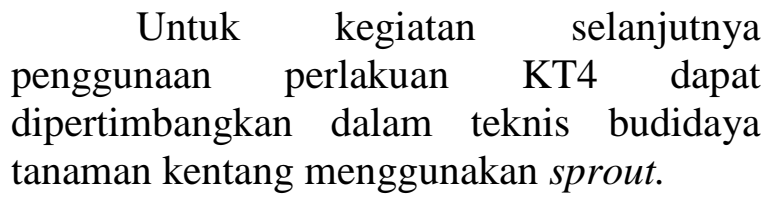

\section{DAFTAR PUSTAKA}

Asandhi, A.A. 1993. Third-Elevation Potato Varieties Grown from Tuber Let

Ashari, S.2006. Hortikultura Aspek Budidaya. Penerbit Universitas Indonesia. Jakarta.

Ashari.S. 2008. Hortikultura Aspek Budidaya Edisi Revisi. Universitas Indonesia Press

Balai Penelitian Tanaman Sayuran. 2007. Petunjuk Teknis Budidaya Tanaman Sayuran. Pusat Penelitian Dan
Pengembangan Hortikultura Badan Penelitian Dan Pengembangan Pertanian.

Balai Pengkajian Teknologi Pertanian Jambi. 2010. Buklet : Budidaya Tanaman Sayuran. Balai Besar Pengkajian Dan Pengembangan Teknologi Pertanian Badan Penelitian Dan Pengembangan Pertanian Kementerian Pertanian.

Balai Pengkajian Teknologi Pertanian (BPTP) Jawa Barat. 2015. Petunjuk Teknis Budidaya Kentang. Badan Penelitian Dan Pengembangan Pertanian Kementerian Pertanian.

Badan Pusat Statistik.2017. Data Produksi Tanaman Kentang di Indonesia

Badan Pusat Statistik. 2018. Data Produksi Tanaman Kentang di Kabupaten Solok Darwin.2000. Pengaruh Berbagai Ukuran Umbi dan Kedalaman Tanam terhadap Pertumbuhan dan Produksi Kentang dari Umbi Bibit Benih Botani Fak. Pertanian Universitas lampung

Fachtulach, D. 2016. Pengaruh Jarak Tanam dan Kedalaman Tanam terhadap Pertumbuhan dan Hasil Tanaman Kentang (Solanum tuberosum L.) Generasi Dua (G2) Varietas Granola. Prosiding Seminar Nasional Pengembangan Teknologi Pertanian. 95-105.

Kamil, J. 1989. Teknologi Benih. Rajawali, Jakarta.

Khalafalla, A. M. 2001. Effect of Plant Density and Seed Size on Growth anD Yield of Solanum Potato in Khortum State, Sudan. African Crop Science J.

Setiawati,W. Dkk. 2007. Katalog Teknologi Inovatif Sayuran. Balai Penelitian Tanaman Sayuran Pusat Penelitian Dan Pengembangan Hortikultura Badan Penelitian Dan Pengembangan Pertanian. 